\title{
DAMPAK MEROKOK TERHADAP POLA TIDUR
}

\author{
${ }^{1}$ Galant Rompas \\ ${ }^{2}$ Nancy Engka \\ ${ }^{2}$ Damayanti Pangemanan
}

\author{
${ }^{1}$ Kandidat Skripsi Fakultas Kedokteran Universitas Sam Ratulangi Manado \\ ${ }^{2}$ Bagian Fisiologi Fakultas Kedokteran Universitas Sam Ratulangi Manado \\ Email:gal_zhadow11@yahoo.ca
}

\begin{abstract}
Sleep/rest is one of human needs, sleep disorder such as insomnia can interfere our daily activities. In Indonesia, the prevalence reached $10 \%$ of people with insomnia, one primary causes of insomnia is smoking. In Indonesia, smoking population aged $\geq 15$ years old reached up to $34,7 \%$. This research is based on analytic survey with cross sectional analytic study. This research aimed to determine the association between insomnia with active smokers. The Population of this study is all of public transport drivers who live in Manado, North Sulawesi. Sample of this study is part of the public transport drivers with total samples 52 participants.The results showed that $23 \%$ of active smokers with insomnia. The result of chi-square test showed that there is a significant correlation $(\mathrm{p}<0.05)$ between insomnia and duration of smoking $(\mathrm{p}=0.004)$, insomnia and active smokers $(\mathrm{p}=0.023)$. There is an association between insomnia and active smokers.
\end{abstract}

Keywords: Insomnia, Active Smokers, Duration of smoking.

\begin{abstract}
Abstrak: Tidur merupakan salah satu kebutuhan manusia, gangguan tidur seperti insomnia dapat mengganggu aktivitas sehari-hari. Di Indonesia prevalensi penderita insomnia mencapai $10 \%$, salah satu faktor penyebab insomnia adalah merokok. Populasi perokok di Indonesia untuk usia $\geq 15$ tahun mencapai $34,7 \%$. Penelitian ini berdasarkan survey analitik dengan rancangan cross sectional study, bertujuan untuk mengetahui hubungan antara insomnia dengan perokok aktif. Populasi dari penelitian ini adalah seluruh sopir angkutan umum yang berada di Kota Manado Sulawesi Utara. Sampel dari penelitian ini adalah sebagian dari sopir angkutan umum yang berada di Kota Manado Sulawesi Utara. Jumlah keseluruhan sampel yang diambil adalah 52 orang. Hasil penelitian menunjukkan bahwa 23\% perokok aktif terdiagnosa insomnia. Dari hasil uji chi-square penelitian ini menunjukkan adanya hubungan yang bermakna ( $<0.05)$ antara : 1$)$ insomnia dengan lama merokol 10 tahun $(\mathrm{p}=0.004)$, 2 ) insomnia dengan perokok aktif $(p=0.023)$. Ada hubungan antara insomnia dengan perokok aktif.
\end{abstract}

Kata kunci: Insomnia, Perokok aktif, Lama merokok.

Hampir sepertiga umur manusia dihabiskan untuk tidur. Tidur yang lelap tanpa gangguan menjadi kebutuhan manusia yang esensial, sama pentingnya dengan kebutuhan makan, minum, tempat tinggal dan lainlain. Gangguan terhadap tidur pada malam hari atau yang lebih dikenal dengan istilah insomnia akan menyebabkan rasa mengan- tuk sepanjang hari. Mengantuk itu sendiri merupakan faktor resiko terjadinya kecelakaan, mudah jatuh, penurunan stamina pada seseorang. ${ }^{1}$

Berdasarkan laporan dari berbagai negara untuk kasus insomnia itu sendiri kira-kira 30\% orang dewasa mengalami satu atau lebih gejala insomnia seperti sulit 
tidur, sulit mengatur waktu tidur, bangun tidur terlalu awal, dan kualitas tidur yang buruk. $^{2}$ Dilaporkan juga dalam sebuah penelitian di Amerika Serikat, sekitar 15\% total populasi mengalami gangguan insomnia yang serius. ${ }^{3}$ Di Indonesia, prevalensi penderita insomnia diperkirakan mencapai $10 \%$, yaitu sekitar 23 juta jiwa penduduk. ${ }^{4,5}$

Secara garis besar ada berbagai macam faktor yang menyebabkan insomnia, salah satunya adalah merokok, dimana kandungan nikotin didalam rokok dapat mengacaukan pola tidur seseorang yang membuat penggunanya selalu waspada dan terjaga.,6

Penelitian sebelumnya melaporkan bahwa prevalensi kurang tidur pada perokok aktif (17,8\%) lebih banyak dibandingkan dengan mantan perokok (10 $\%)$ dan bukan perokok $(9,4 \%)^{7}$. Selain itu penelitian yang dilakukan terhadap remaja yang merokok dengan usia 15-17 tahun, hanya $1 \%$ yang mengalami gejala insomnia. ${ }^{8}$ Penelitian sebelumnya yang dilakukan terhadap 97 mahasiswa dilaporkan bahwa, dari 66,6\% mahasiswa yang merokok $42 \%$ diantaranya mengalami gangguan tidur. ${ }^{9}$ Penelitian lain yang dilakukan pada mahasiswa dilaporkan bahwa 3,5\% mahasiswa yang menggunakan alkohol, rokok, dan zat adiktif lainnya terkena insomnia. ${ }^{10}$

Dari data Riset Kesehatan Dasar (Riskesdas) tahun 2010 dilaporkan bahwa sekitar 34,7\% penduduk di Indonesia yang berusia $\geq 15$ Tahun adalah perokok dan yang paling banyak berada di Provinsi Kalimantan Tengah yaitu sekitar 43,1\% penduduknya adalah perokok. Di Sulawesi Utara sendiri dilaporkan sekitar 36,2\% jumlah penduduknya adalah perokok. ${ }^{11}$

Dari data menurut jenis kelamin jumlah perokok pada laki-laki (sekitar 70\%) lebih banyak dibandingkan dengan perempuan (sekitar 4\%). Sementara orang yang tinggal di perkotaan dan di pedesaan tidak ada perbedaan yang berarti mengenai data jumlah perokok. Sementara itu jumlah perokok jika dilihat dari segi umur, kelompok umur 45-54 dilaporkan oleh Riskesdas memiliki prevalensi paling tinggi yaitu sekitar $38 \%$ perokok. ${ }^{11}$
Seperti yang telah dibahas bahwa merokok merupakan salah satu faktor pencetus kesulitan tidur pada seseorang, dan besarnya prevalensi perokok khususnya di Provinsi Sulawesi Utara. Sehingga menjadi perhatian tersendiri bagi peneliti untuk meneliti hubungan antara gangguan tidur dalam hal ini insomnia dengan penggunaan rokok.

\section{METODE}

Penelitian ini berdasarkan survey analitik dengan rancangan cross sectional study. Penelitian ini bertujuan untuk mengetahui hubungan antara insomnia dengan perokok aktif pada sopir angkutan umum yang berada di Terminal Malalayang Kota Manado Sulawesi Utara.

Populasi dari penelitian ini adalah seluruh sopir angkutan umum yang berada di Kota Manado Sulawesi Utara. Sampel dari penelitian ini adalah sebagian dari sopir angkutan umum yang berada di Kota Manado Sulawesi Utara. Jumlah keseluruhan sampel yang diambil adalah 52 orang. Hasil penelitian akan didistribusikan kedalam diagram dan akan dianalisis dengan program SPSS.

\section{HASIL PENELITIAN}

Penelitian ini merupakan penelitian observasional analitik dengan menggunakan rancangan cross sectional study yang dilakukan sejak bulan Desember 2012 di Terminal Malalayang Manado.

Peneliti mengambil data responden pajanan pada laki-laki karena yang diambil adalah sopir angkutan umum yang kebanyakan berjenis kelamin laki-laki, sementara itu karena kurangnya sopir nonperokok maka peneliti mengambil variable kontrol berjumlah 26 responden rata-rata diluar sopir angkutan umum.

\section{Distribusi responden}

Dari data pada gambar 1 dapat dilihat bahwa dari 26 perokok aktif yang menjadi sampel dilaporkan 6 orang terdiagnosis 


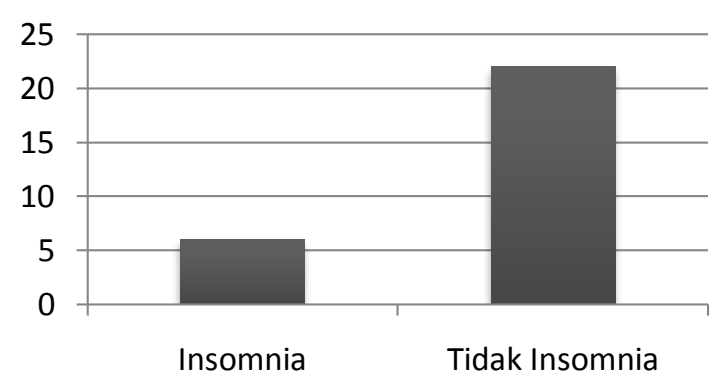

Gambar 1. Perokok aktif yang terdiagnosa insomnia dan tidak.

insomnia atau sekitar 23\%, sedangkan yang tidak terdiagnosa insomnia berkisar 20 orang atau sekitar $77 \%$.

Data menurut jenis kelamin tidak diuraikan karena yang diambil dalam penelitian ini adalah sopir angkutan umum (bus, mikrolet, minibus, dll) yang hampir semua berjenis kelamin laki-laki dan sangat jarang ditemukan jenis kelamin wanita.

Selanjutnya akan dijabarkan data mengenai lama merokok dari sampel yang terdiagnosa insomnia dan tidak.

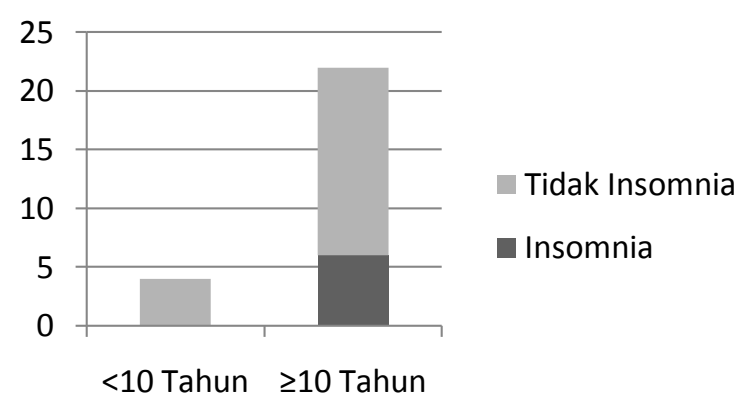

Gambar 2. Insomnia berdasarkan lama merokok.

Dari data pada gambar 2 terlihat bahwa kebanyakan perokok aktif khususnya sopir angkutan umum di terminal malalayang sudah merokok lebih dari 10 tahun dan hanya sedikit yang merokok dibawah 10 tahun.

Data yang ditemukan dari 26 responden yang memenuhi kriteria inklusi ditemukan 4 responden $(15,4 \%)$ dengan lama merokok $<10$ tahun, dan sisanya yaitu 22 responden $(84,6 \%)$ telah merokok $\geq 10$ tahun.

Dari seluruh responden yang merokok $<10$ tahun tidak ditemukan adanya insomnia, sedangkan responden yang me-rokok $\geq 10$ tahun ditemukan sekitar 6 responden $(27,3 \%)$ yang terdiagnosa insomnia.

Selanjutnya akan dijabarkan hasil berdasarkan banyaknya rokok yang dihisap oleh responden setiap harinya.

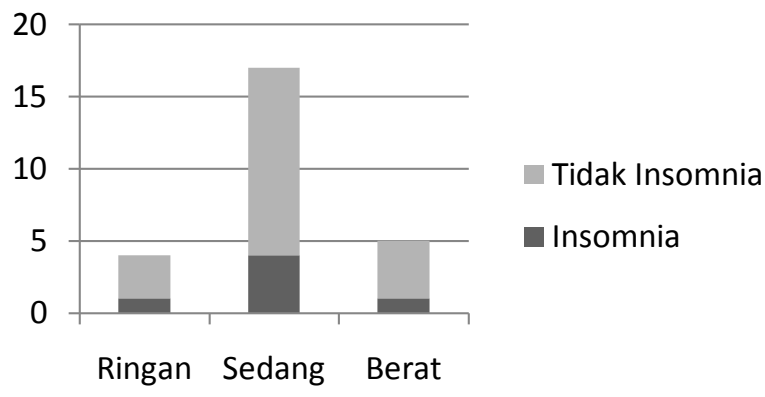

Gambar 3. Insomnia berdasarkan jumlah rokok.

Dari data pada gambar 3 responden paling banyak berada dalam kategori perokok sedang yaitu 17 responden (65,4\%), sedangkan untuk kategori perokok ringan dan perokok berat tidak ada perbedaan yang berarti dimana perokok ringan terdapat 4 responden $(15,4 \%)$, dan perokok berat 5 responden (19,2\%).

Berdasarkan jumlah rokok yang dihisap jika dilihat dari jumlah responden yang terdiagnosa insomnia, paling banyak terdapat pada kategori perokok sedang yaitu 4 responden, dibandingkan dengan perokok ringan dan perokok berat yang hanya 1 responden.

Berdasarkan distribusi frekuensi belum ada perbedaan yang berarti, seperti yang ada dalam gambar 3 perokok ringan (25\%), perokok sedang (23,5\%), dan perokok berat (20\%).

Selanjutnya akan dipaparkan mengenai variabel kontrol yang diteliti dalam hal ini responden yang bukan perokok aktif.

Data pada gambar 4 diambil peneliti sebagai variabel kontrol untuk perbandingan 


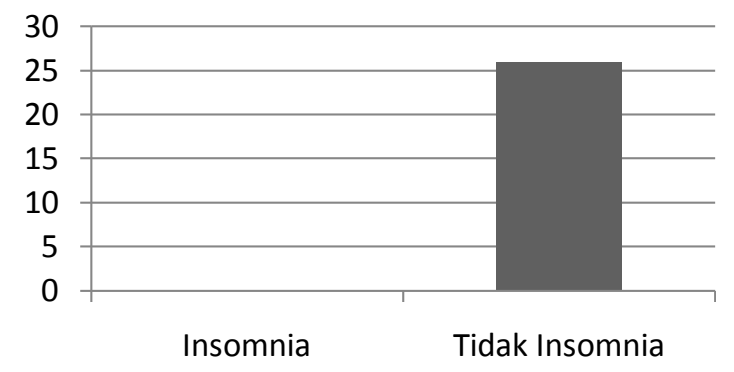

Gambar 4. Non perokok yang terdiagnosa Insomnia dan tidak.

dengan variabel pajanan.

Data yang diambil sebanyak 26 responden yang tidak merokok dan tidak terpapar dengan faktor-faktor resiko dari insomnia.

Dari data yang diambil seluruh responden tidak terdiagnosa insomnia. Selanjutnya akan dipaparkan perbandingan keduanya antara perokok aktif dan bukan perokok.

\section{Analisis data}

Hasil uji chi-square pada tabel 1 diperoleh nilai $P=0.004$ menunjukkan bahwa ada hubungan antara insomnia dengan lama merokok.

Hasil uji chi-square pada tabel 2 diperoleh nilai $P=0.023$ menunjukkan bahwa

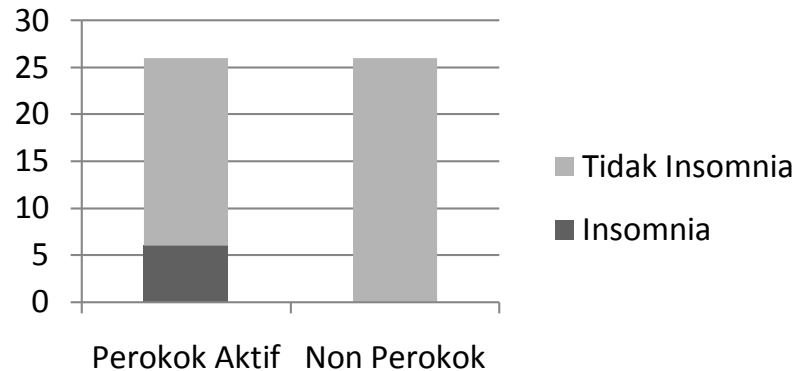

Gambar 5. Perokok aktif dan non perokok.

ada hubungan antara insomnia dengan perokok aktif.

\section{PEMBAHASAN}

Hasil penelitian yang didapat oleh peneliti sudah diamati dengan baik agar sesuai dengan kriteria inklusi. Untuk itu ada beberapa data yang dieleminasi oleh peneliti karena tidak masuk kriteria inklusi untuk variabel pajanan yaitu perokok aktif.

Data yang dieleminasi oleh peneliti salah satunya berhubungan dengan faktor umur, dimana ada beberapa sampel yang berumur lebih dari yang ditentukan dalam kriteria inklusi.

Data lain yang dieleminasi oleh peneliti yaitu responden yang mantan perokok, data ini dieleminasi karena

Tabel 1. Hubungan insomnia dengan lama merokok.

\begin{tabular}{|c|c|c|c|c|c|c|c|}
\hline \multirow{3}{*}{ Lama Merokok } & \multicolumn{4}{|c|}{ Keadaan Responden } & \multirow{2}{*}{\multicolumn{2}{|c|}{ Jumlah }} & \multirow{3}{*}{ Nilai $\mathbf{P}$} \\
\hline & \multicolumn{2}{|c|}{ Insomnia } & \multicolumn{2}{|c|}{ Tidak Insomnia } & & & \\
\hline & $\mathbf{n}$ & $\%$ & $\mathbf{n}$ & $\%$ & $\mathbf{n}$ & $\%$ & \\
\hline $\begin{array}{l}\text { Tidak Merokok dan Merokok } \\
<10 \text { Tahun }\end{array}$ & 0 & 0 & 30 & 100 & 30 & 100 & 0.004 \\
\hline Merokok $\geq 10$ Tahun & 6 & 22.3 & 16 & 77.7 & 22 & 100 & \\
\hline
\end{tabular}

Tabel 2. Hubungan Insomnia dengan perokok aktif

\begin{tabular}{|c|c|c|c|c|c|c|c|}
\hline \multirow{3}{*}{ Perokok } & \multicolumn{4}{|c|}{ Keadaan Responden } & \multirow{2}{*}{\multicolumn{2}{|c|}{ Jumlah }} & \multirow{3}{*}{ Nilai $\mathbf{P}$} \\
\hline & \multicolumn{2}{|c|}{ Insomnia } & \multicolumn{2}{|c|}{ Tidak Insomnia } & & & \\
\hline & n & $\%$ & $\mathbf{n}$ & $\%$ & $\mathbf{n}$ & $\%$ & \\
\hline Perokok Aktif & 6 & 23 & 20 & 77 & 26 & 100 & 0.023 \\
\hline
\end{tabular}


yang diteliti oleh peneliti adalah perokok aktif, meskipun ada penelitian yang membuktikan bahwa mantan perokok bisa mengalami gangguan tidur namun hasilnya masih dibawah perokok aktif. ${ }^{7}$

Data yang diperoleh oleh peneliti harus dibandingkan dengan variabel kontrol untuk memperoleh nilai kemaknaan. Sama halnya dengan variabel pajanan, variabel kontrol yang diambil peneliti juga diseleksi untuk menghindari kesalahan dalam pengolahan data.

Peneliti mengambil variabel kontrol yang bukan merupakan perokok aktif. Data yang dieleminasi oleh peneliti berhubungan dengan faktor-faktor yang bisa mencetus insomnia.

Data yang dieleminasi oleh peneliti salah satunya adalah perokok pasif, dalam suatu penelitian dikatakan bahwa perokok pasif beresiko tinggi mengalami gangguan tidur dibandingkan dengan yang bukan perokok pasif atau yang tidak terpajan dengan asap rokok. ${ }^{7}$

Data lain yang dieleminasi oleh peneliti adalah variabel kontrol yang lama terpajan dengan alat elektronik, pola tidur yang tidak teratur, dan penggunaan kafein. Faktor-faktor tersebut merupakan beberapa penyebab yang dapat memicu terjadinya insomnia. ${ }^{12}$

\section{Hubungan antara insomnia dengan lama merokok}

Dari hasil uji chi-square menunjukkan adanya hubungan antara lama merokok seseorang dengan kejadian insomnia, hal ini ditunjukkan dengan nilai $P<0.05$. Data ini sesuai dengan teori yang menyatakan bahwa merokok $\geq 10$ tahun beresiko tinggi untuk terpapar berbagai gangguan dalam tubuh, dalam hal ini insomnia. ${ }^{13}$

\section{Hubungan antara insomnia dengan perokok aktif}

Dari hasil uji chi-square menunjukkan adanya hubungan antara insomnia dengan perokok aktif. Hal ini sesuai dengan penelitian sebelumnya yang menyatakan bahwa terjadi gangguan tidur pada perokok aktif yang lebih tinggi dibandingkan dengan orang yang tidak merokok maupun mantan perokok.

Prevalensi pada usia dewasa jauh lebih meningkat dibandingkan dengan prevalensi pada usia remaja. Hal ini dapat dilihat dari penelitian sebelumnya yang dilakukan pada perokok aktif usia remaja(15-17 tahun), yang mengalami gejala insomnia hanya sekitar 1\% saja dari keseluruhan responden yang diteliti. ${ }^{8}$ Data ini berbeda jauh prevalensinya dengan data yang didapat oleh peneliti, dimana perokok aktif usia dewasa(18-50 tahun) yang terdiagnosa insomnia berkisar 23\%.

Data yang ditemukan oleh penelitian sebelumnya pada remaja masih terbilang wajar. Hal ini dikarenakan pada usia remaja banyak yang tergolong perokok aktif berisiko rendah, yaitu mereka yang memiliki durasi atau lama merokok $<10$ tahun. Berbeda dengan data yang ditemukan peneliti pada usia dewasa, ratarata responden merupakan perokok aktif berisiko tinggi, yaitu mereka yang memiliki durasi atau lama merokok $\geq 10$ tahun.

Penelitian sebelumnya yang dilakukan terhadap mahasiswa mendukung penelitian ini, dimana hasil penelitian menunjukkan adanya hubungan antara perilaku merokok dan stres dengan insomnia. ${ }^{9}$

Prevalensi dari penelitian sebelumnya terhadap mahasiswa lebih tinggi jika dibandingkan dengan penelitian ini. Dari $66,6 \%$ mahasiswa yang merokok 42\% diantaranya mengalami insomnia. ${ }^{9}$ Dibandingkan dengan penelitian ini hanya 23\% responden perokok aktif yang terdiagnosa insomnia.

Hasil dari penelitian sebelumnya pada mahasiswa jika dibandingkan dengan hasil penelitian ini masih terbilang wajar, karena pada penelitian sebelumnya pada mahasiswa ditambahkan salah satu faktor psikologis yaitu stres. ${ }^{12}$ Faktor ini dapat 
mempengaruhi peningkatan angka kejadian insomnia. Hal itu dapat kita lihat pada penelitian sebelumnya jika dibandingkan dengan penelitian saat ini.

Penelitian lain yang dilakukan juga pada mahasiswa dilaporkan bahwa sekitar 3,5\% mahasiswa yang terpapar dengan alkohol, rokok, dan zat adiktif terkena salah satu dampak negatif yaitu insomnia. ${ }^{10}$

Hasil ini lebih rendah dibandingkan dengan penelitian yang dilakukan oleh peneliti, karena penelitian ini bertujuan untuk mencari hubungan dengan perokok aktif sedangkan penelitian sebelumnya hanya mencari gambaran secara umum. Namun data ini menunjukkan bahwa merokok dapat menyebabkan seseorang terdiagnosa insomnia.

Dari keseluruhan data pada penelitian sebelumnya baik kecil maupun besar prevalensinya, menunjukkan bahwa seseorang perokok aktif memiliki kemungkinan untuk terdiagnosa insomnia. Hal ini juga turut didukung dengan adanya hubungan antara insomnia dengan perokok aktif pada penelitian ini (nilai $\mathrm{p}=0.023$ ).

\section{SIMPULAN}

Berdasarkan pembahasan maka dapat ditarik kesimpulan bahwa ada hubungan antara insomnia dengan perokok aktif. Perokok aktif yang beresiko tinggi yaitu merokok $\geq 10$ tahun lebih memiliki resik o insomnia lebih besar dibandingkan dengan yang bukan perokok maupun perokok $<10$ tahun.

\section{UCAPAN TERIMA KASIH}

Ucapan terima kasih disampaikan pada dr. J. J. V. Rampengan, AIFM, AIFO sebagai penguji 1 , dr. S. Supit, AIFM, AIFO sebagai penguji 2, dan pada semua pihak yang baik secara langsung maupun tidak langsung telah menumbuhkan ide tau gagasan dalam pemikiran penulis sehingga dapat menyelesaikan artikel ini.
1. Rahayu RA. Gangguan tidur pada usia lanjut. In: Sudoyo AW, Setiyohadi B, Alwi I, Simadibrata M, Setiati S, editors. Ilmu Penyakit Dalam jilid 1 (Edisi Kelima). Jakarta: Interna Publishing, 2009; p.802.

2. Roth T. Insomnia: definition, prevalence, etiology, and consequences. J Clin Sleep Med. 2007;3(5):S7-10.

3. Putra SR. Tips sehat dengan pola tidur tepat dan cerdas. Yogyakarta: Buku biru, 2011; p.125-7.

4. Medicastore. Dampak insomnia terhadap kesehatan tubuh [homepage on the Internet]. 2010 [updated 2010 Jun 05; cited 2012 okt 27]. Available from: http://medicastore.com/seminar/108/Damp ak_Insomnia_Terhadap_Kesehatan_Tubuh. html

5. Dampak insomnia bagi kesehatan [homepage on the Internet]. 2012 [updated 2012 Mar 05; cited 2012 okt 27]. Available from: http://www.dokterkuonline.com/index.php/article/59-dampakinsomnia-bagi-kesehatan

6. Smoking and insomnia- a guide to stop smoking [homepage on the Internet]. Nodate [cited 2012 okt 27]. Available from: http://www.medic8.com/healthguide/ smoking/problems-smoking/smokinginsomnia.html

7. Sabanayagam C, Shankar A. the association between active smoking, smokeless tobacco, secondhand smoke exposure and insufficient sleep. Sleep Med 2011;12(1):7-11.

8. Komalasari D, Helmi AF. faktor-faktor penyebab perilaku merokok pada remaja. Jurnal Psikologi Universitas Gadjah Mada 2000.

9. Purnomo. Hubungan perilaku merokok dan stress dengan insomnia pada mahasiswa fakultas ilmu kesehatan universitas muhammadiyah surakarta. Surakarta: Universitas Muhammadiyah Surakarta; 2011.

10. Kurniawati DE, Warsini S, Marchira CR. Gambaran skrining keterlibatan penggunaan alkohol, rokok dan zat adiktif pada mahasiswa D3 fakultas teknin universitas gadjah mada. Berita Kedokteran Masyarakat. 2010:26(2):90-9.

11. Badan Penelitian dan Pengembangan Kesehatan Kementrian Kesehatan RI. Riset kesehatan dasar. Jakarta: Bakti Husada; 2010.

\section{DAFTAR PUSTAKA}


282 Jurnal e-Biomedik (eBM), Volume 1, Nomor 1, Maret 2013, hlm. 276-283

12. Widya G. Mengatasi insomnia : cara mudah mendapatkan kembali tidur nyenyak anda. Jogjakarta: Katahati, 2010; p.15-21.

13. Ismara KI. Rokok dan bahayanya [homepage on the Internet]. Nodate [cited
2012 nov 22]. Available from: http://staff.uny.ac.id/sites/default/files/peng abdian/drs-ketut-ima-ismara-mpd-

mkes/presentasi-rokok-dan-bahayanya.pdf 